DOI: https://doi.org/10.31933/dijms.v2i1 Received: 15 July 2020, Revised: 15 August 2020, Publish: 10 September 2020

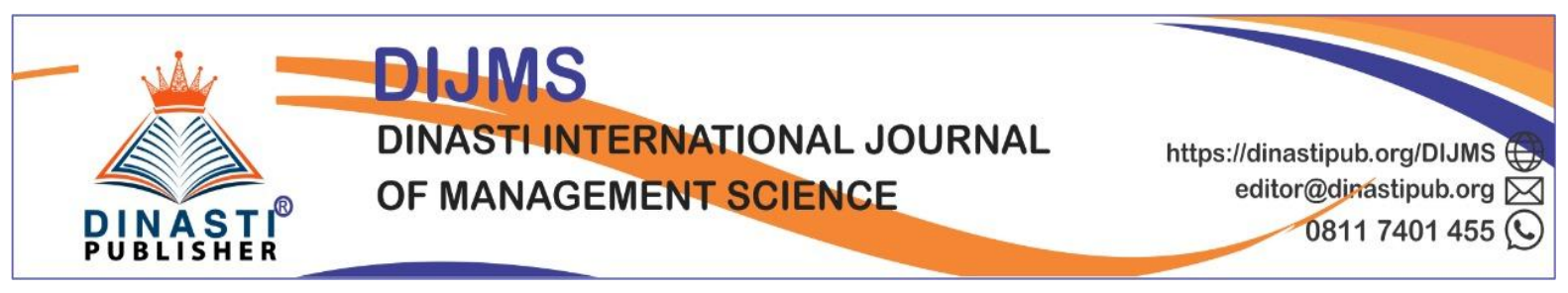

\title{
WORK SATISFACTION VALUE VIEWED FROM REACTION OF TRANSFORMATIONAL LEADERSHIP, PERFORMANCE ASSESSMENT AND TRAINING VARIABLES
}

\author{
Aji Peri Sandria ${ }^{1)}$ Irfan Noviandy Aulia ${ }^{2)}$ \\ ${ }^{1)}$ Master of Management in Mercu Buana University, Jakarta, Indonesia, sandriaaji@gmail.com \\ ${ }^{2)}$ Lecturer of Postgraduate in Mercu Buana University, Jakarta, Indonesia, \\ irfan.noviandy@mercubuana.ac.id
}

\section{Corresponding Author: First Author}

Abstract: This research was done because wants to explore regarding those influence which come from transformational leadership, performance assessment and training against work satisfaction at PT Pelat Timah NusantaraTbk in Cilegon. This research has include in qualitative research by causality design to prove those causal relationship between several variables such as transformational leadership (X1), performance assessment (X2), training (X3) and work satisfaction (Y). samples used which amounted to 99 people with sampling technique used non probality sampling and sample selected was done by random sampling. Scores of statements on questionnaire used a Likert scale of 1-5. Data analysis used SEM (Structural Equation Modeling) or Structural Equation Model whereas data processed by Partial Least Square (Smart-PLS) version 3.0. These results from research could be defined as follows: transformational leadership has mutual reaction to work satisfaction, performance assessment has beneficial impact over work satisfaction, training has positive influence towards work satisfaction and transformational leadership, performance assessment and training simultaneously influence on work satisfaction at PT Pelat Timah NusantaraTbk in Cilegon.

Keywords: Transformational leadership, performance assessment, work satisfaction and training.

\section{INTRODUCTION}

Employees are very important assets for a company to survive in this business industry. It was because in fact these employees who was run those company operations, such as production machines, managing finances also selling products. Therefore its common if companies try to give a good treatment to employees so these employees would feel satisfied, according to Wibowo (2017:424) at organizational level, high satisfied workers will tend to get everything done quickly and effective than organizations who has less satisfied workers. Beside that, high work satisfaction could reduce the risk of turnover and those plays up attitude and irresponsibility from employees, As the answer to work dissatisfaction according 
to Robbins \& Judge (2013:82) could created lots of employee resignatiom from company (exit) or an neglect attitude such as absence or delay.

Those employee departure (resignation) from company would certainly has big impact towards company. According to Mathis \& Jackson (2004) that quoted from Elmi (2018:197) stated that a huge loss from these employee resignation is bearing with costs that should be incurred such as recruitment costs, training costs, productivity costs and dismissal costs. Not to mention all entird time wasted for adapting process by his successor. Similarly, if there has violation committed by employees such as absent or coming late or coming home early, it will certainly disrupt those company's operations because there has chance that those works cannot be done due to lack of people who do that work.

PT Pelat Timah Nusantara Tbk. (PT LatinusaTbk.), A manufacturing company who domiciled at KIEC Industrial Estate Cilegon Banten, has an experiencing problems with an increase of turnover percentage and also high number of employee trespass. From these data that obtained, the following data could be earned such as:

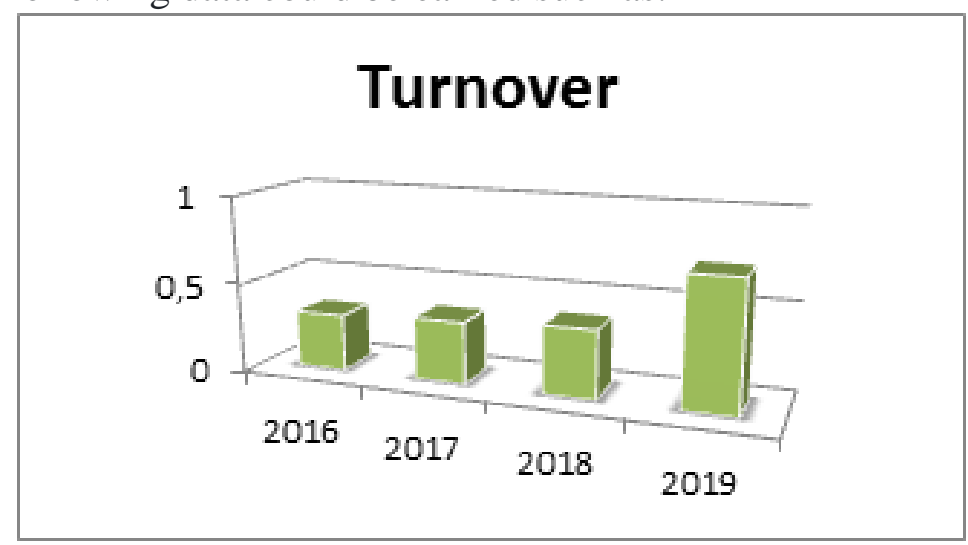

Figure 1. Turnover Percentage Data Due to Resignation 2016-2019

Source: PT LatinusaTbk Internal Data (2019)

From this figure it could tell that turnover percentage of employees who resigned from 2016 to 2019 has increased. In 2016 turnover percentage was $0.32 \%$, then rose to $0.35 \%$ in 2017 , increased again to $0.38 \%$ in 2018 and finally to $0.72 \%$ in 2019 .

Table 1. Employee Breach Data of PT Latinusa Tbk. 2019

\begin{tabular}{|c|c|c|c|c|c|c|c|c|c|}
\hline \multirow{2}{*}{ No } & \multirow{2}{*}{ Type of Violation } & \multicolumn{8}{|c|}{ Quantity in 1 month (2019) } \\
\hline & & Jan & Feb & Mar & Apr & May & Jun & Jul & Ags \\
\hline 1 & Arriving late / Going home too soon & 127 & 146 & 100 & 108 & 103 & 71 & 68 & 111 \\
\hline 2 & Absent & 95 & 95 & 66 & 64 & 70 & 45 & 77 & 90 \\
\hline 3 & Lost to & 29 & 26 & 28 & 28 & 31 & 20 & 18 & 5 \\
\hline & Total & 251 & 267 & 194 & 200 & 204 & 136 & 163 & 206 \\
\hline
\end{tabular}

Source: PT LatinusaTbk Internal Data (2019)

Based on disciplinary violations data above, it is defines that there was an increase and decrease in violations that occurred during period of January 2019 to August 2019, but form of violations from month to month remained above the number 100 which indicates still often done by employees. The least number of violations occurred in June 2019, which is 136 
violations. Whereas the highest number of violations occurred in February 2019, with total number of 267 violations.

Wibowo (2017: 426) explained that leaving the company (resigning) was one of attitudes that taken due to work dissatisfaction. Its similiar with statement from Robbins \& Judge (2013: 82) They said that resigning is one of reaction towards work dissatisfaction that leads to behavior leaving the organization, including finding new positions and resigning, and also neglect in the form of late or absent, can also a response to work dissatisfaction.

From these explanation above then the researcher hired 20 respondents who were employees at PT Latinusa Tbk. regarding which aspects that could impact to work satisfaction, These following data could be drawn as follows:

Table 2. Pre-Survey Results regarding which Factors that could Affecting Employee Satisfaction

\begin{tabular}{clcccccc}
\hline No & \multicolumn{1}{c}{ Statement } & STS & TS & N & S & SS & Score \\
\hline 1 & I'm satisfied with leadership & 1 & 7 & 9 & 3 & 0 & $\mathbf{5 4}$ \\
\hline 2 & I'm satisfied with compensation & 0 & 4 & 10 & 6 & 0 & 62 \\
\hline 3 & I'm satisfied with performance assessment & 2 & 9 & 6 & 2 & 0 & $\mathbf{4 8}$ \\
\hline 4 & I'm satisfied with training that conducted & 4 & 8 & 5 & 3 & 0 & $\mathbf{4 7}$ \\
\hline 5 & I'm satisfied with the organizational culture & 1 & 3 & 9 & 6 & 1 & 63 \\
\hline 6 & I'm satisfied with work motivation & 1 & 4 & 8 & 6 & 1 & 62 \\
\hline 7 & I'm satisfied with communication & 0 & 5 & 6 & 8 & 1 & 65 \\
\hline 8 & I'm satisfied with safety and health & 1 & 1 & 5 & 10 & 3 & 73 \\
\hline
\end{tabular}

From these pre-survey results which explained above, it is well known that occupational health and safety factors got highest value, which is 73 from expected value of 100. This indicate that employees at PT Latinusa Tbk. most satisfied with health and safety that provided by company compared to 7 other factors. Meanwhile, from these pre-survey results its common if training, performance Assessment and leadership, each scored 47, 48 and 54 from expected value of 100, so that those three factors in row get the least good response while compared to other factors.

\section{LITERATURE REVIEW \\ Work Satisfaction}

Robbins \& Judge (2013: 79) was defined that work satisfaction as pleasure feelings about work which result from evaluating its characteristics. Meanwhile Luthans (2011: 141)was described that work satisfaction as an employee perceived result about how well their companies would provides something that considered to be important. Hidayat et al (2018)was explained that work satisfaction has involves psychological individuals in organization, which caused by situation that they feels from their environment and that feeling will appear from employee good attitude towards work and everything which encountered in work environment.

From those explanation above it could be concluded that work satisfaction is feeling or assessment from employee towards its environment, whether good or bad thing. Those Conditions could be affect someone's work satisfaction include: work stress, compensation, leadership, performance Assessment, organizational culture, training, work environment, communication and safety and occupational health. 
Luthans (2011: 142) was explained that those dimensions from work satisfaction include: type of work, appropriate payment, opportunities for promotion, supervision received by employees and types of colleagues related to employees.

\section{Transformational Leadership}

Robbins and Judge (2013: 368) was defined leadership as an ability to influence groups to achieve a vision or set of goals that are set. Burns (1978) in Gancer (2016) was described two types of leadership, such as : transformational leadership and transformational leadership. Transformational leadership is type of leadership where the leaders could change the values, beliefs, attitudes, behaviors, emotions and demands of followers into a better orientation in the future, Bass (1978) in Muslichah et al (2018).

A good leader was inspires theirs subordinates to fullest extent possible, works hard to achieve the best results and given to subordinates for their hard work, in hoping to increase work satisfaction, motivation, performance and loyalty. Therefore according to Bertocci (2009)that quoted from Wulandari, et al (2018), leaders have a clear vision about current situation of organization, where direction of organization should be run and how organization would headed up in that right direction.

Bass and Avolio (1994) in Suwatno and Prinasa (2016: 159), suggested that there are four dimensions from transformational leadership with concept of 4I that consist of Idealized Influence, Inspirational Motivation, Intellectual Simulation and Individualized Consideration.

\section{Performance Assessment}

Rivai and Basri (2005: 14) stated that measurement of performance is a systematic results of studies or overall level of success from a person during certain period in carrying out their task compared to various possibilities, such as work standards, targets or goals and those criteria who have agreed upon. Meanwhile Elmi (2018: 110)was defined performance Assessment as an evaluation system periodicly towards employee performance that supports over success on organization and related to implementation of its duties.

From some of these definitions which explained above, it could be concluded that performance evaluation is process to evaluating these achievement from employee's performance with targets set in certain period, performance assessment is important as an effort to provide feedback or appreciation so employee performance in the future would be better. Elmi (2018: 113) was explained that performance evaluation criteria could be seen from several dimensions, including functional, valid, empirical and systematic criteria.

\section{Training}

Careel and Kuzmits (1982) which quoted from Elmi (2018: 63) and explained that training is an activity Which aims to improve those employee skills, reduce learning time to help operational problems and also prepare for promotion. Meanwhile Saprudin (2018)was defined that employee training or learning as a systematic effort by these company to improve all knowledge, skills and work attitudes of employees through learning process so it is optimal in carrying out these functions and duties of theirs position . Robbins and Coulter (2015: 371)was explained that there are several training methods, including on the job 
training, rotation, mentoring and coaching, experience training, manuals / books and classroom training.

From those various definitions as mentioned above, it could be concluded that training is a systematic process to improve employee competency or skills with a variety of methods. These employee goal could increased theirs competence so he could be more prepared and confident to do work given.

Careel and Kuzmits (2010) in Elmi (2018: 63)was explained that there were several training indicators including improving employee skills, reducing study time, helping operational problems and preparing for promotions.

These research model in this research could be defined as follows:

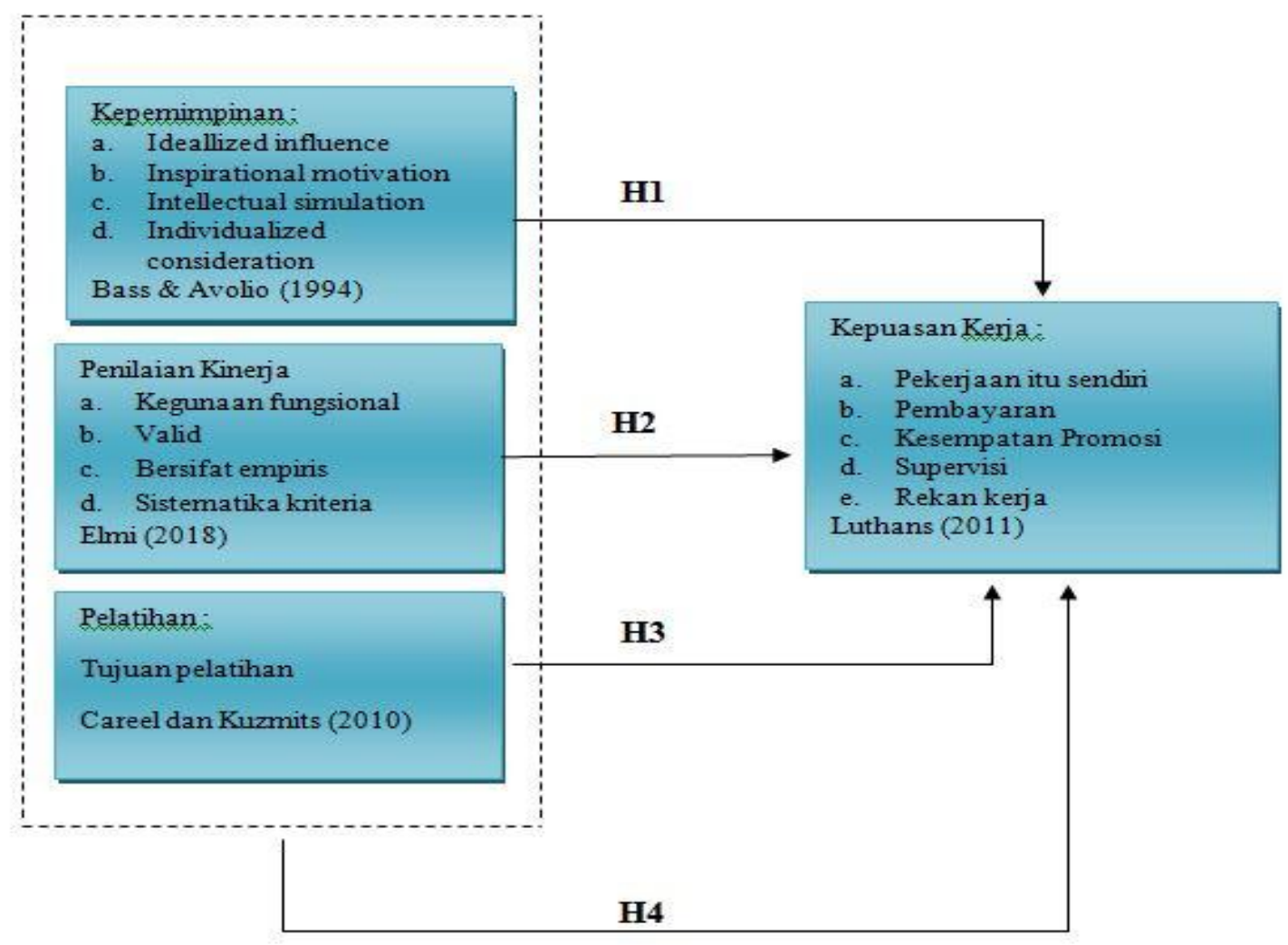

Figure 2. Research Model

\section{Research Hypothesis}

H1: Leadership has an mutual influence over Work Satisfaction.

H2: Performance Assessment has an positive influence towards work Satisfaction.

H3: Training has an beneficial impact to work Satisfaction.

H4: Transformational Leadership, Performance Assessment and Training has simultaneously influence on work Satisfaction.

\section{Research Methods}

This research is qualitative research, which is a research method based on Philosophy of positivism also called scientific method because it fills the scientific principles of concrete/ empirical, objective, measurable, rational and systematic, Sekaran \& Bougie (2017:3). The research design used causality to prove those causal relationship which occurs 
between several variables such as three variables that are free (Independent) with variables that are attached (dependent). Independent variables include transformational leadership (X1) performance Assessment (X2) and training (X3). Meanwhile those dependent variable is work satisfaction (Y).

Population from this research were employees from PT Latinusa Tbk Cilegon, which worked for more than 2 (two) years so that performance assessment from these 132 people that has been carried out, which could be divided by gender, age, education and position. Then was estimated using Slovin formula to gained sample of 99 people. The sampling technique used in this research is non probality sampling, meaning that not all population units has chance to used as a sample, Bungin (2013:112). Meanwhile those selection sample was done by Random Sampling, ie taking sample members from population which done randomly without regard to strata in population, Sugiono (2017: 82). Then each statement was given a score using score to determine the weight of the assessment based on a Likert scale with a scale of 1-5. Likert scale used to measure those attitudes, opinions and perceptions from a person or group of people regarding social phenomena, Sugiono (2017:93). In this research, Analysis technique used SEM (Structural Equation Modeling) data analysis technique or Structural Equation Model whereas the data processing used Partial Least Square (Smart-PLS) version 3.0.

\section{RESULTS AND DISCUSSIONS}

Characteristics of respondents. According to questionnaire results as its follows: male respondents were 89 people (90\%), while female respondents were 10 people (10\%). In terms of respondents aged 21-40 years as many as 21 people (21\%), aged 31-40 years as many as 35 people $(35.5 \%)$, aged $41-50$ years as many as 8 people (8\%) and aged 51-55 years as many as 35 people $(35.5 \%)$. In terms of educational those respondents with high school education totaled 54 people (55\%), D3 totaled 2 people (2\%), S1 totaled 37 people $(37 \%)$ and S2 totaled 6 people (6\%). In terms of work position of respondents who work as General Manager amounted to 4 people (4\%), Head of Divisions amounted to 12 people (12\%), Section Heads totaled 13 people (13\%), Section Heads totaled 44 people (45\%) and Implementers totaled 26 people $(26 \%)$.

\section{Measurement of Model Test and Outer Model}

Outer Model or commonly called outer relation or measurement model, was defines how each block of indicators relates to its latent variable, Ghozali (2014:37). In outer model, validity and reliability test was performed. Validity test was done through convergent validity and discriminant validity test. While reliability test was performed by composite reliability and Cronbach's Alpha.

Following this is a picture of models value among constructs on work Satisfaction research while model was obtained by SmartPLS 3.0. From this figure, the loading factor value from each construct as obtained such as: 


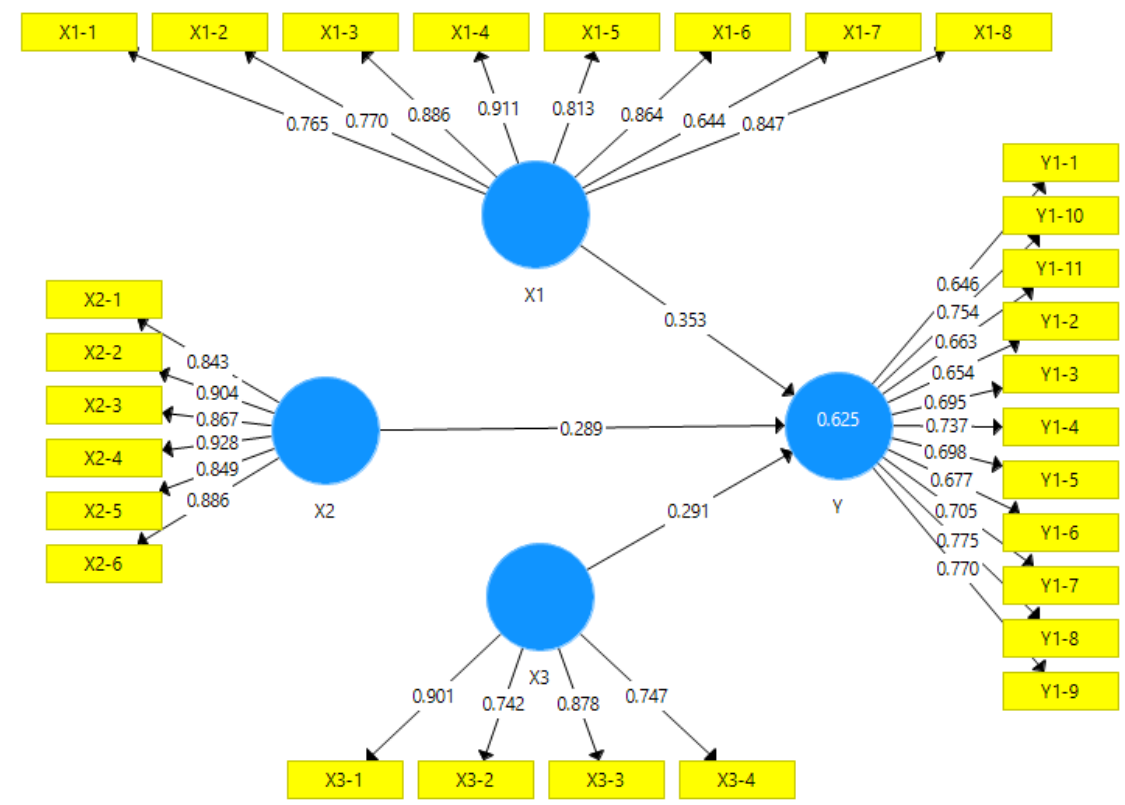

Figure 3. Models value Between Research Model Constructions

According to this figure, it is common that factor loading values from each variable above 0.60 , which could be a measure in this research. According to Ghozali (2014: 65)these value of 0.50 to 0.60 still acceptable, therefore all indicators used in this reseach has fulfilled convergent vadilidity and considered valid.

Based on Ghozali (2014:40) those average variance extracted (AVE) value is good if the value greater than 0.50 . From these AVE estimations value which was done by SmartPLS 3.0, AVE value from transformational leadership variable is 0.667 , performance Assessment is 0.774 , training is 0.673 and work satisfaction is 0.501 . So all AVE values are greater than 0.5 and therefore its concluded that this research model is valid.

In measurement of composite reliability construct were declared reliable if those composite value is above 0.70, Ghozali (2014: 65). From those calculation using SmartPLS 3.0, composite reliability of transformational leadership was 0.941 , performance assessment was 0.954, training was 0.891 and work satisfaction was 0.917 . Because those composite reliability value of all variables was above 0.70 , therefore its declared reliable.

In measurement of Cronbach's alpha construct, its stated to be reliable if value of Cronbach's alpha is above 0.70, Ghozali (2014: 65). From these calculations results which performed by SmartPLS 3.0, these cronbach's alpha variable value from transformational leadership is 0.927, performance Assessment is 0.941, training is 0.837 and work satisfaction is 0.900 . Because all Cronbach's alpha value from all variables is above 0.70, therefore its declared to be reliable.

\section{Structural Model Evaluation (Inner Model)}

From these calculation of R-Square it is discover that R-Square value from work satisfaction variable (Y) is equal to 0.625 . It shows that $62.5 \%$ from work satisfaction variable (Y) was influenced by transformational leadership (X1), performance assessment (X2) and training (X3). While remaining of $37.5 \%$ was influenced by other variables thats not examined in this research. 


\section{Hypothesis Test}

To see how great influence (significance) from relationship between variables that could be seen from these tvalue of statistics by Path Coeffients (Ghozali, 2014: 67). The t test formulation can be seen through comparison between $t$ test values with ttable value that obtained from these formulation: $\mathrm{DF}=\mathrm{n}-\mathrm{k}-1=99-3-1=95$.

In these statistical table, so $t$ table 95 was equal to 1.985 with strong effect to level of 0.05. The method of decision making such as: If P-Values $>0.05$ or $t$ count $<\mathrm{t}$ table, therefore Ho was accepted, and if P-Values $<0.05$ or $\mathrm{t}$ count $>\mathrm{t}$ table, therefore Ho was rejected.

The results from original sample, $\mathrm{t}$ statistics and $\mathrm{P}$ value Estimation by SmartPLS 3.0, it could be seen as follows:

Table 3. Original Sample, $t$ Statistic and P-Values

\begin{tabular}{cccc}
\hline Relationship Between Constructions & Original Sample & t Statistic & P Value \\
\hline Transformational Leadership " Work Satisfaction & 0,353 & 3,158 & 0,002 \\
\hline Performance Assessment " Work Satisfaction & 0,289 & 3,260 & 0,001 \\
\hline Training " Work Satisfaction & 0,291 & 3,242 & 0,001 \\
\hline
\end{tabular}

From table 3 result its recognize that the value of $\mathrm{t}$ statistics is 3.158 which greater than value of $t$ tables (1.985). The P-Values was obtained is 0.002 which less than $\alpha$ of 0.05 . Thus H1 hypothesis in this research states that "transformational leadership has an mutual reaction on work satisfaction" was accepted.

According to table 3 results it is recognize that $t$ statistics value is 3.260 which greater than $\mathrm{t}$ table value (1.985). The P-Values was obtained is 0.001 , which less than $\alpha$ of 0.05 . Thus $\mathrm{H} 2$ hypothesis in this research which stated that "performance assessment has a positive reaction towards work satisfaction" was accepted.

From the results from table 3 was described that the value of $t$ statistics is 3.242 which greater than value of $t$ tables (1.985). The P-Values was reached 0.001 , which less than $\alpha$ of 0.05 . Thus H3 hypothesis which states that "training has a positive on work satisfaction" was accepted.

In order to find out simultaneously influence between transformational leadership (X1), performance Assessment (X2) and training (X3) towards work satisfaction (Y), this research use these following additional formula, Mahmud (2016):

$$
\text { Fhit }=\frac{\mathrm{R}^{2}(\mathrm{n}-\mathrm{k}-1)}{\left(1-\mathrm{R}^{2}\right) \mathrm{k}}
$$

From the data obtained its recognize that R-Square (R2) is $0.625(62.5 \%)$ and the number of samples in this research is 99 with significance level $\alpha$ is $5 \%$ or 0.05 , then $\mathrm{F}$ count and $\mathrm{F}$ table values could obtained as its follows :

Meanwhile $\mathrm{F}$ table $=\mathrm{Fa}(\mathrm{k}, \mathrm{n}-\mathrm{k}-1)=\mathrm{F} 0.05(3.99-3-1)=\mathrm{F} 0.05(3.95)=2.70$ (obtained from $\mathrm{F}$ table). From these estimation above, it is recognize that $\mathrm{F}$ count is $53.15 \geq \mathrm{F}$ table is 2.70, thus $\mathrm{H} 4$ hypothesis in this research which stated that "transformational leadership, performance Assessment and training have a simultaneously influence over work satisfaction" was accepted.

\section{Discussions}


From these hypothesis test research which conducted on the first hypothesis, was known as transformational leadership has positive influence towards work satisfaction. This proven by $\mathrm{t}$

$\mathrm{t}$ statistical value (3.158) which greater than $\mathrm{t}$ table value (1.985) and $\mathrm{P}$ Values $(0.002)$ is less than the $\alpha(0.05)$ value. It could be interpreted that the better transformational leadership that carried out by the leader, the work satisfaction will also increase and conversely. Based on that, $\mathrm{H} 1$ was accepted and $\mathrm{H} 0$ was rejected.

From these hypothesis test research that conducted from second hypothesis, its recognize those performance assessment has a positive impact over work satisfaction. This could be said that the more just and objective performance assessment carried out will increase these work satisfaction on employees, because what has been done could be assessed properly. Therefore, $\mathrm{H} 2$ was accepted and $\mathrm{H} 0$ was rejected. This proven by t statistical value (3.260) which greater than $\mathrm{t}$ table value (1.985) and the P Values (0.001) which smaller than the $\alpha(0.05)$ value.

From these hypothesis test result which conducted on third hypothesis, its well known that training has a positive effect on work satisfaction. This proven by $t$ statistical value (3.242) which greater than $t$ table value (1.985) and the $P$ Values (0.001) which smaller than the $\alpha(0.05)$ value. This could be interpreted that training provided in accordance of needs employees and it could increase work satisfaction with company and vice versa. Based on this, H3 was accepted and H0 was rejected.

From these hypothesis test result which conducted on fourth hypothesis, it is recognize that transformational leadership, performance assessment and training has simultaneously influence against work satisfaction. Those calculation results show that the Fcount (53.15) has greater than value from F Table (2.70). Based on H4 was accepted and H0 was rejected.

\section{CONCLUSION AND SUGGESTIONS Conclusion}

Transformational leadership has an beneficial reaction over work satisfaction at PT Pelat Timah Nusantara Tbk. Cilegon. The results showed the better the transformational leadership which carried out by the leader, the work satisfaction has increased and conversely.

Performance Assessment has an mutual reacted over work satisfaction at PT Pelat Timah Nusantara, Tbk. Cilegon. This could be said that the more fair and objective on scoring it will increase work satisfaction conversely.

Training has an positive influence over work satisfaction at PT Pelat Timah Nusantara, Tbk. Cilegon. Those training which provided in accordance with employee needs will increase employee work satisfaction with company.

Transformational leadership, performance assessment and training have a simultaneously influence against work satisfaction. meaning that all three variables consisted start from transformational leadership, performance Assessment and training has simultaneously affect to work satisfaction. 


\section{Suggestions}

To General Manager it is advise to hold an coordination meeting periodically every 2 weeks. Meanwhile for Head division, Section Heads, Section Heads and operationals has to prepare submitted reports at coordination meeting, furthermore General Manager could provide these instructions needed by his subordinates.

Its suggested that an objection reporting system to be made for these assessments on Employee Service System (ESS) put easily accessed by employees until operational level therefore any objections regarding performance assessment could be followed up immediately

Its recommended for Company to provide training to employees who will get promotions in according to the needs of position.

Its recommended to the Human Capital Management Division to review salaries and compensation which currently given to employees based on salary surveys that apply in other similar companies, City / Regency Minimum Wages, Sectoral Miminum Wages and company capabilities.

As for further researchers who were interested in research about work satisfaction, it is suggested to use other variables besides transformational leadership variables, performance Assessment and training, such as compensation, career development, communication, organizational culture or any other variables.

\section{REFERENCES}

Burham Bungin, (2013). Metodologi Penelitian Sosial \& Ekonomi. Jakarta: Kencana Prenada Media Grup.

Elmi Farida, (2018). Telisik Manajemen Sumber daya Manusia. Ed 1. Jakarta: Mitra Wacana Media.

Ghozali, Imam. (2014). Structural Equation Modeling Metode Alternatif Dengan Partial Least Squares. Ed 4. Semarang: Badan Penerbit Universitas Diponegoro.

Luthans, Fred. (2011). Organizasional Behavior. Ed 12. New York : Mc Grow-Hill Irwin.

Mehmet Salih Gençera , Assist. Prof. Dr. Yavuz Samurb. (2016). Leadership Styles and Technology: Leadership Competency Level of Educational Leaders. Procedia Social and Behavioral Sciences Vol. 229 pp $226-233$.

Muslichah, Sobikhul Asrori. (2018). The Effect of Transformational Leadership Style on Job Satisfaction with Trust-In-Leader as Intervening Variable. Journal of Innovation in Business and Economics Vol. 02 No. 02 pp. 61-70.

Puji Wulandari dan Hamidah Nayati Utami (2018). Hubungan Kepemimpinan Dan Kepuasan Kerja Dengan Loyalitas Pegawai (Studi Pada Pegawai Kantor PT Pembangkitan Jawa-Bali Unit Pembangkit Brantas). Jurnal Administrasi Bisnis, Vol. 65

Rahmad Hidayat, Teddy Chandra, dan Harry P. Panjaitan (2018). Influence Of Organizational Culture, Work Motivation, And Leadership Style On Job Satisfaction And Employee Performance At Gas Stations In Rokan Hilir. Kurs, Vol. 3 No. 2.

Rivai, Veithzal \& Basri Ahmad Fawzi M. (2005). Performance Appraisal. Depok: Raja Grafindo Persada.

Saprudin. (2018). Pengaruh Pelatihan Dan Kompensasi Terhadap Kepuasan Kerja Karyawan. Journal of Information System, Applied Management, Accounting and Research. Vol. 2.

Stephen P Robbins \& Mary Coulter. (2016). Manajemen. Ed 13. Jakarta: Erlangga. 
Stephen P. Robbins \& Timothy A. Judge. (2013). Organizational Behavior. Ed 15. United States of Amerika: Pearson Education.

Sugiono. (2017). Metode Penelitian Kuantitatif, Kualitatif dan $R \&$ D. Bandung: Alfabeta.

Suwatno \& Donni Juni Priansa. (2016). Manajemen SDM Dalam Organisasi Publik dan Bisnis. Bandung: Alfabeta.

Uma Sekaran \& Roger Bougie. (2017). Metode Penelitian Bisnis. Jakarta: Salemba Empat. Wibowo. (2017). Manajemen Kinerja. Ed.5. Depok: Raja Grafindo Persada. 